\title{
Catalytic, Asymmetric Inverse Electron Demand Hetero Diels-Alder Reactions of o-Benzoquinone Derivatives and Ketene Enolates
}

\author{
Daniel H. Paull, Jamison Wolfer, James W. Grebinski, Anthony Weatherwax, and Thomas Lectka*
}

\begin{abstract}
We present an array of [4+2] cycloaddition reactions between ketene enolates, catalytically derived from acid chlorides and cinchona alkaloid nucleophilic catalysts in the presence of stoichiometric base, and o-benzoquinone derivatives. These cycloaddition reactions proceed with excellent stereochemical control (up to $>99 \%$ ee). In fact, for both the o-benzoquinone imide and the o-benzoquinone diimide manifolds, these Diels-Alder reactions occurred with uniformly $>99 \%$ ee. The wide scope of this methodology provides access to a diverse range of biologically and synthetically useful chiral products, including $\alpha$-hydroxyesters, non-natural $\alpha$-amino acids, quinoxalinones, and many others, all with remarkable, catalytic control of regio- and stereochemistry.
\end{abstract}

Keywords: Asymmetric catalysis · Bifunctional catalysis · [4+2] Cycloaddition · Hetero Diels-Alder · Ketene enolates

\section{Introduction}

Catalytic, enantioselective cycloaddition reactions of $p$-quinones are well documented. ${ }^{[1]}$ The products of these reactions are potentially very useful in the realm of natural product synthesis. However, little work has been done on the catalytic, asymmetric reactions of $o$-quinones and derivatives. $o$-Quinones have a potentially much richer reactivity spectrum - cycloaddition reactions may involve the ring carbons (as in the well-studied $p$-quinone isomers), but more interestingly, reactions may proceed through the $o$-heteroatoms to provide useful bicyclic products (Scheme 1).

\footnotetext{
${ }^{*}$ Correspondence: Prof. T. Lectka

Department of Chemistry

Johns Hopkins University

$3400 \mathrm{~N}$. Charles St.

Baltimore, MD 21218, USA

Tel.: +1 4105166448

Fax: +1 4105167044

E-Mail: lectka@jhu.edu
}

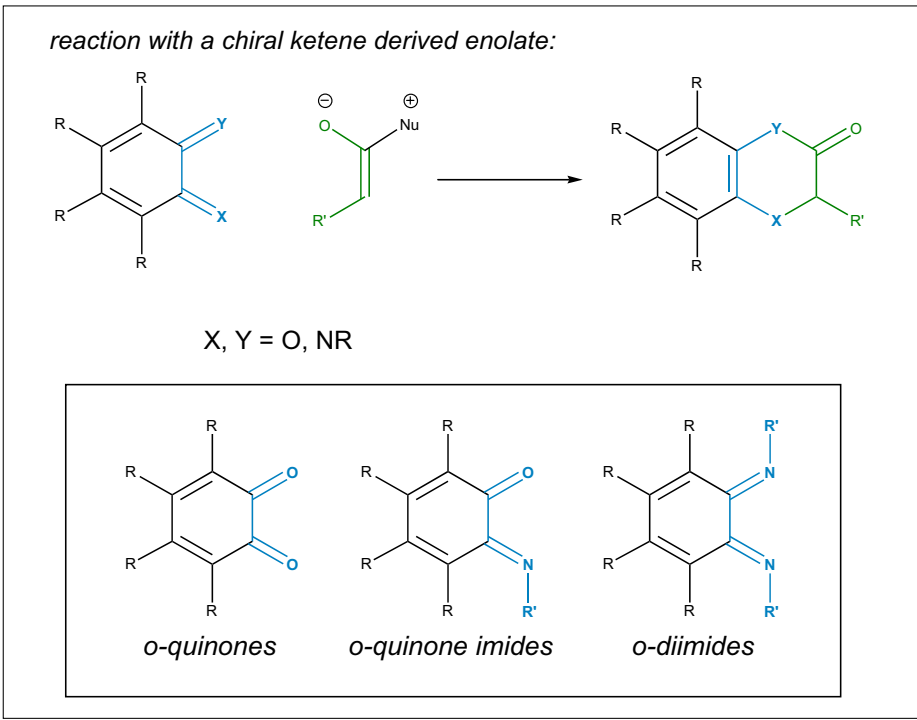

Scheme 1. o-Benzoquinones as substrates for asymmetric ketene enolate cycloadditions

While the products of these cycloadditions are interesting and useful as chiral building blocks for organic synthesis, both they and their readily obtained derivatives show even greater utility and promise in a variety of physiological applications. For example, the $\alpha$-hydroxy esters obtained from $o$-quinones have found application as inhibitors of amyloid- $\beta$ (A $\beta)$ protein production, and thus show promise in the treatment of Alzheimer's disease. ${ }^{[2]}$ Chiral $\alpha$-oxygenated carboxylic acid products can also be derivatized in a variety of useful ways. $o$-Quinone imides can provide easy access to invaluable, non-natural $\alpha$-amino acids (both protected and unprotected), which find uses in all areas of biochemical study. Quinone imides also provide access to oxazinones and oxazines, bicyclic products that are useful as antitumor agents, 


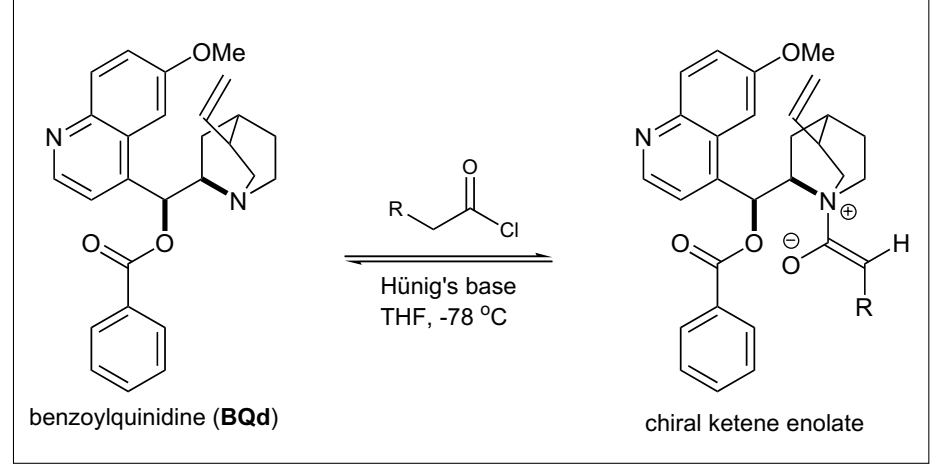

Scheme 2. Catalytic generation of ketene enolate

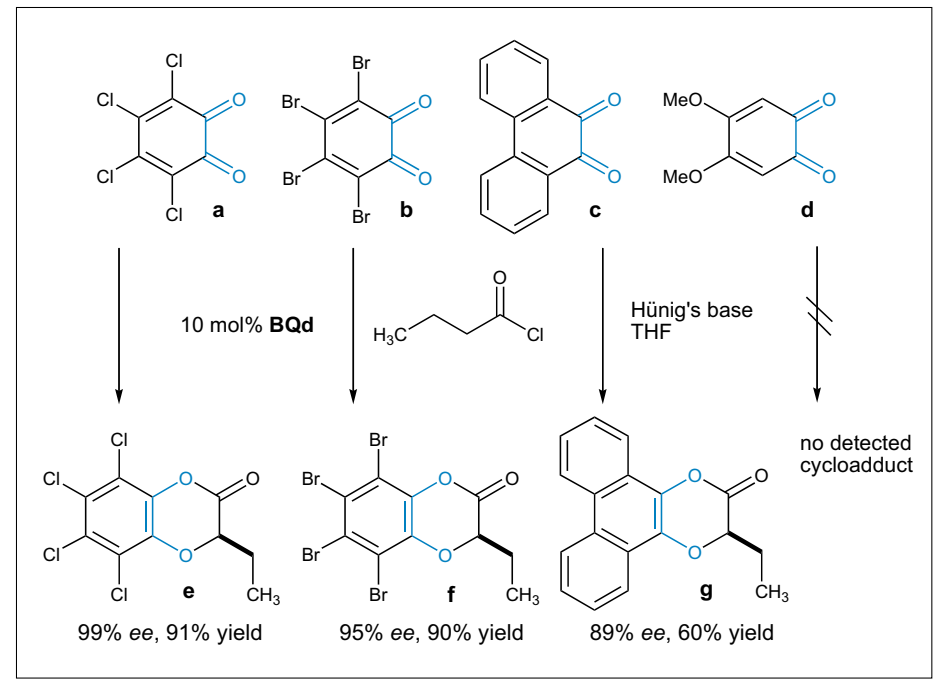

Scheme 3. Preliminary o-quinone reactions

topoisomerase inhibitors, and antibiotics. ${ }^{[3]}$ $o$-Benzoquinone diimides produce quinoxalinones and their quinoxaline derivatives, all of which exhibit a wide range of biological activity including antiviral effects, particularly against retroviruses such as HIV. ${ }^{[4]}$

The use of chiral, catalytically-derived zwitterionic 'ketene' enolates have provided the means for the synthesis of diverse, optically enriched products. Chiral ketene enolates are well known for their highly enantioselective reactions to form $\beta$-lactones and $\beta$-lactams via $[2+2] \mathrm{cy}$ cloaddition with aldehydes and imines. ${ }^{[5]}$ However, previously, [4+2] cycloaddition reactions of ketene enolates were virtually unknown. The ketene enolates are formed from acid chlorides and a catalytic nucleophile, benzoylquinidine (BQd), or its pseudoenantiomer benzoylquinine (BQ), in the presence of a stoichiometric base (Scheme 2). ${ }^{[6]}$ We recently discovered that these catalytically generated chiral nucleophiles can be used to initiate a cycloaddition reaction with a wide variety of $o$-benzoquinone derivatives to give $[4+2]$ bicycloadducts in good to excellent yield and very good to excellent enantiomeric excess (up to $>99 \%$ ee).

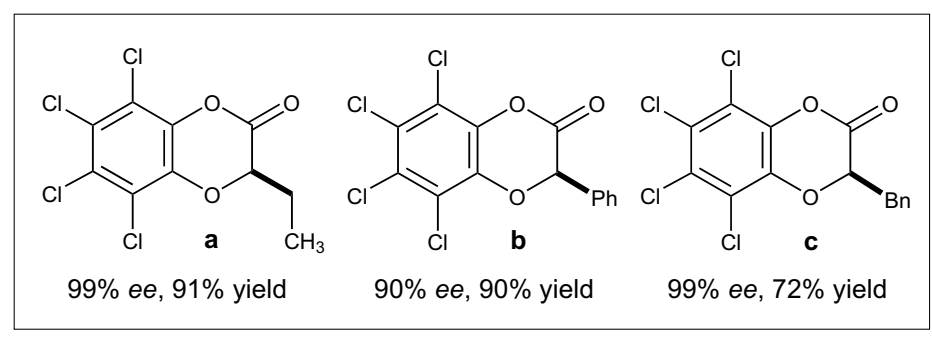

Fig. 1. $o$-Chloranil-derived cycloadducts

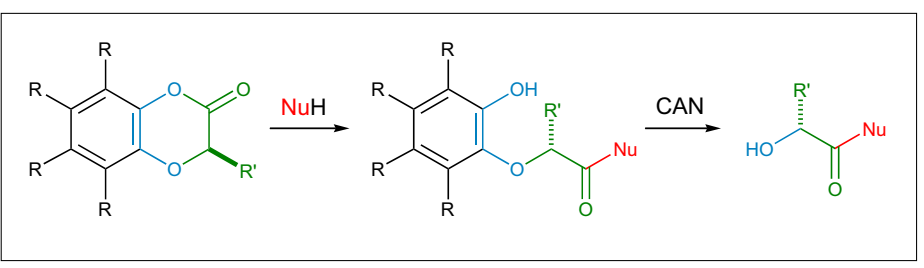

Scheme 4. Derivatization of benzodioxinone cycloadducts

ployed these conditions with all substrates. We also screened $o$-bromanil, which was found to form product $\mathbf{f}$ (Scheme 3) in high ee $(95 \%)$, and $90 \%$ yield. 9,10-Phenanthrenequinone was screened using similar conditions; its reactivity proved to be much lower than $o$-chloranil. However, when the reaction temperature was raised to $0{ }^{\circ} \mathrm{C}$, reaction occurred sluggishly to afford product in reasonable yield. On the other hand, 4,5dimethoxy-o-quinone failed to provide appreciable product under any conditions.

Given the superiority of $o$-chloranil in our initial tests, we decided to investigate its reaction with a variety of acid chlorides. For example, dihydrocinnamoyl chloride performed similarly, affording product c (Fig. 1) in high ee (99\%). Additionally, $\alpha$-arylacetyl chlorides proved to be excellent substrates. For example, phenylacetyl chloride generated product b (Fig. 1) in high yield $(90 \%)$ and good ee $(90 \%)$. Using BQd as catalyst, the $(R)$-enantiomer formed preferentially. The $(S)$-enantiomers can be obtained in similarly high enantioselectivity when benzoylquinine (BQ) is used. This sense of induction held for all quinone derivative substrates, as well as all acid chlorides, and is consistent with other asymmetric reactions that have employed these cinchona alkaloid derivatives to catalytically generate ketene enolates.[14]

The $o$-chloranil-derived cycloadducts can be further modified to produce chiral, $\alpha$-oxygenated carboxylic acid derivatives (Scheme 4). For example, methanolysis of benzodioxinone b (Fig. 1) followed by ceric ammonium nitrate (CAN) oxidation affords (+)-methylmandelate (b, Fig. 2) in excellent yield (95\%) and ee (90\%). For maximum utility, reaction with the nucleophile $\left(\mathrm{H}_{2} \mathrm{O}, \mathrm{ROH}\right.$, or $\left.\mathrm{RNH}_{2}\right)$ may occur in the same pot as the cycloaddition. Depending on how activated the product aromatic ring is, the nucleophilic ring opening may 


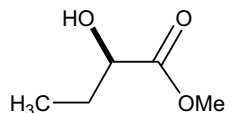

a

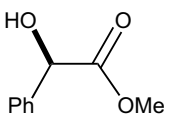

b

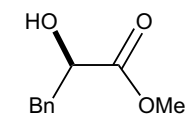

$99 \%$ ee, $86 \%$ yield $90 \%$ ee, $95 \%$ yield $99 \%$ ee, $88 \%$ yield

Fig. 2. $\alpha$-Hydroxyester derivatives

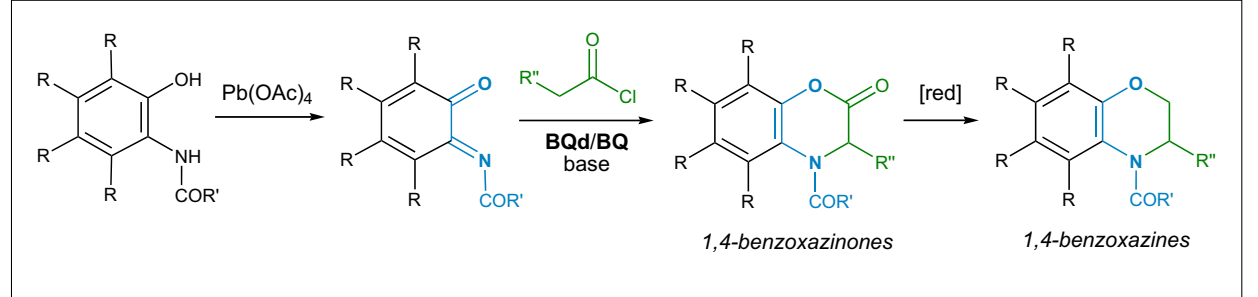

Scheme 5. Synthesis of optically active benzoxazinones and benzoxazines

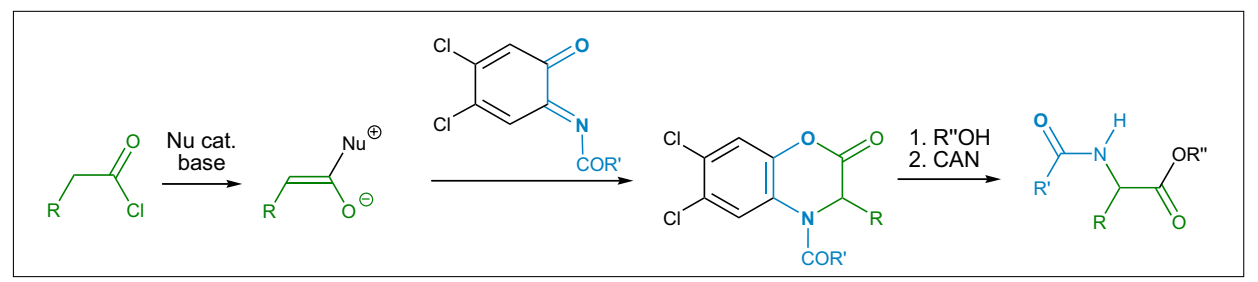

Scheme 6. Quinone imides as amino acid templates

be fast, allowing CAN oxidation to occur in the same pot as well. Thus, the quinone can be thought of as a 'template' for $\alpha$-hydroxycarboxylic acid and ester synthesis. Several other cycloadducts were likewise converted to optically active $\alpha$-hydroxyesters (Fig. 2). In each case, the reaction proceeds in high yield and with full retention of optical activity.

\section{3. o-Benzoquinone Imides}

$o$-Benzoquinone imides are intriguing for several reasons. The products of their cycloaddition with ketene enolates are chiral benzoxazinones and benzoxazines (Scheme 5), interesting compounds with biological potential for which few asymmetric syntheses exist. For example, they have been investigated as antitumor agents, as selective inhibitors of drug metabolism and topoisomerase, ${ }^{[3]}$ and have been shown to possess promising neuroprotective antioxidant activity. ${ }^{[15]}$ Prescription drugs, such as the new generation antibiotic Levaquin (levofloxacin) for example, are also oxazines.[3d] Perhaps most importantly, $o$-benzoquinone imides can function as a scaffold for the synthesis of optically active non-natural $\alpha$-amino acid derivatives (Scheme 6).

The isolable $o$-benzoquinone imides are easily synthesized via lead(IV) oxidation of the corresponding 2-aminophenols. In a phenol ${ }^{[17]}$ as $\alpha$-amino acid templates for a variety of reasons - the starting material is study published in 2001, Nicolaou et al. exDiels-Alder dienes, finding that they react through the $\mathrm{N}$ and $\mathrm{O}$ atoms, as desired. modifying the substituent on N. For examas an acyl group) on the nitrogen should en hance the electrophilicity towards the enolate. Initially we chose to screen quinone
Fig. 3. Benzoxazinone products inexpensive, it can be readily acylated with a virtually limitless variety of substituents, and is easily oxidized to the corresponding quinone imide. The chlorines in the $4-$ and 5-positions are present to block undesired reactivity at the quinone ring, as well as to enhance the overall electrophilicity of the system.

We found that reaction of various combinations of acid chlorides and quinone imides, in the presence of $10 \mathrm{~mol} \% \mathbf{B Q d}$ and Hünig's base in THF at $-78^{\circ} \mathrm{C}$, formed the desired cycloadducts in good yield and uniformly excellent $e e$ ( $>99 \%$ ee in all cases, Fig. 3).[18] The benzoxazinone cycloadducts are also readily converted into benzoxazines. A simple reduction with dimethyl sulfide-borane complex ${ }^{[19]}$ leads to the corresponding benzoxazine (Scheme 7) in good yield and with full retention of $e e$. Oxazines are found in the core structure of many medicinally important compounds, including Levaquin.

The efficient synthesis of non-natural $\alpha$-amino acid derivatives has been a paramount goal of asymmetric catalysis for more than a generation. Many approaches to the synthesis of these compounds rely on metal-based catalysts, for example, asymmetric hydrogenation ${ }^{[20]}$ and Lewis acid catalyzed alkylations. [21] The O'Donnell phase-transfer system is a good example of an 'organocatalyzed' process. ${ }^{[22]}$ One other advance is represented by the asymmetric Strecker reaction, which can be catalyzed by either metal-based or organic systems. [23] We have developed a complementary approach to the synthesis of $\alpha$-amino acid derivatives that relies on an asymmetric cycloaddition of $o$-benzoquinone imides with chiral ketene enolates. The cycloadducts are derivatized in situ to provide the $\alpha$-amino acid derivatives in high chemical yield, and very high enantioselectivity. As a testament to the flexibility of this methodology, a wide
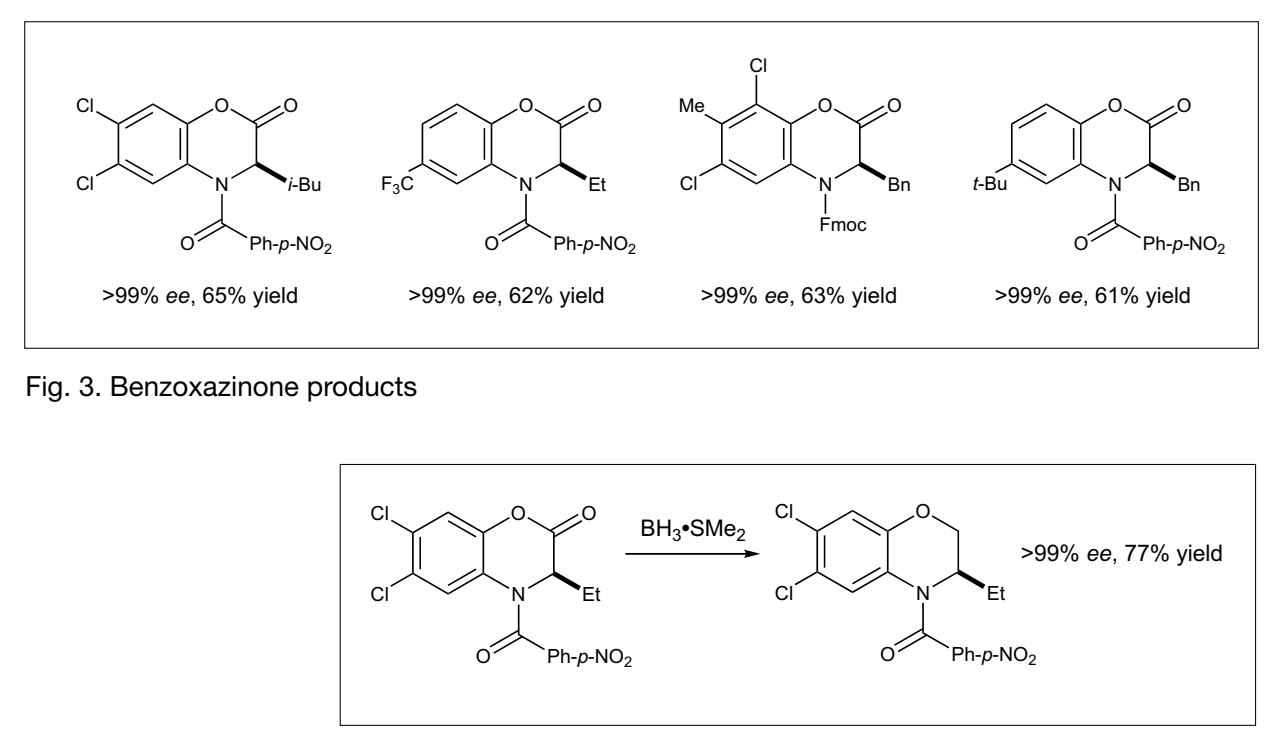

Scheme 7. Reduction to benzoxazines 


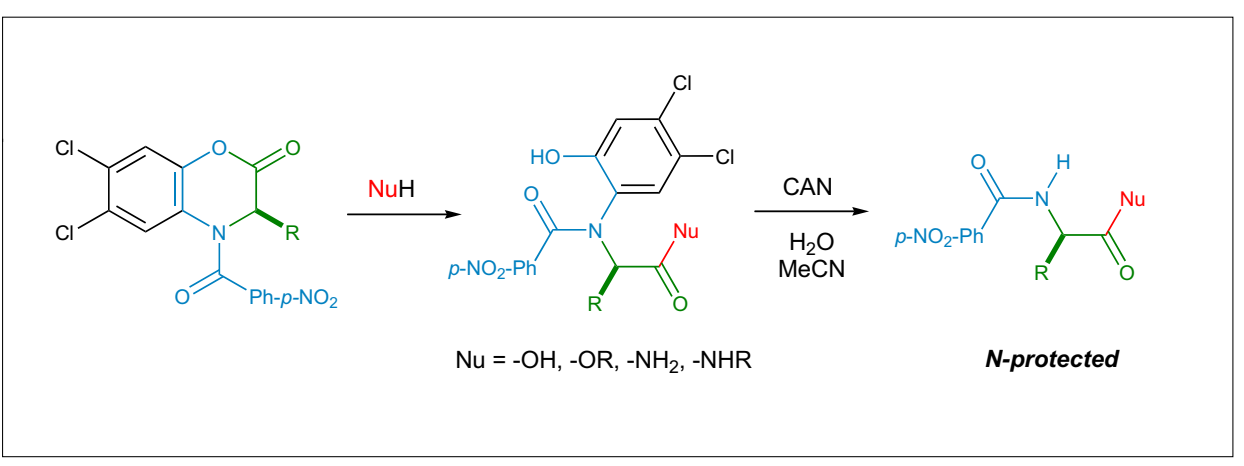

Scheme 8. Synthesis of $\alpha$-amino acid derivatives

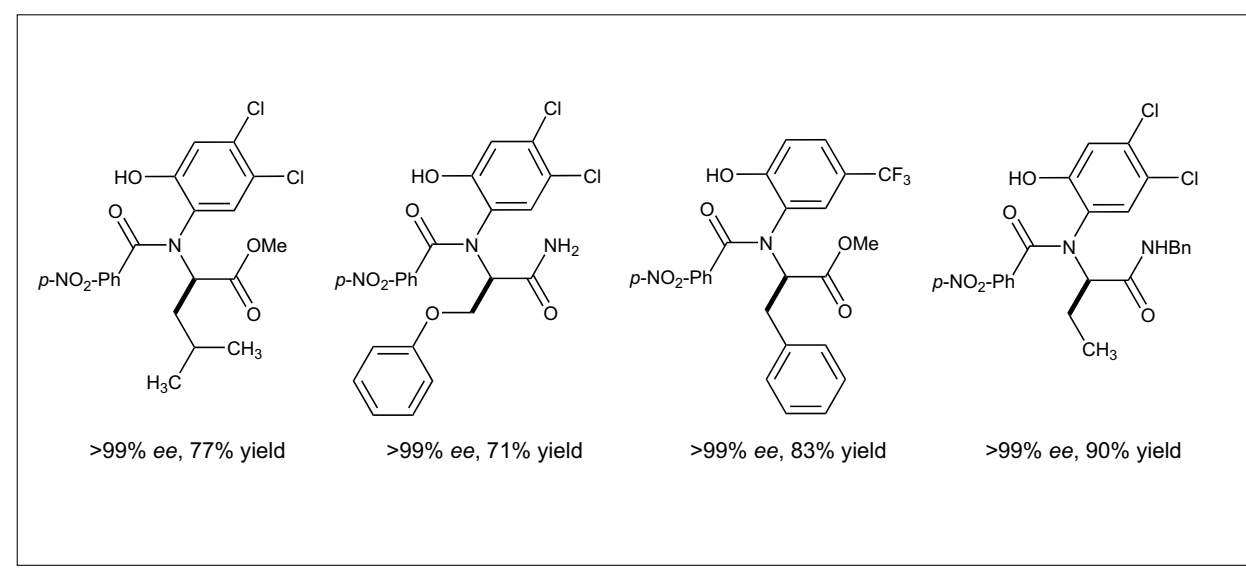

Fig. 4. N-Aryl $\alpha$-amino acid derivatives
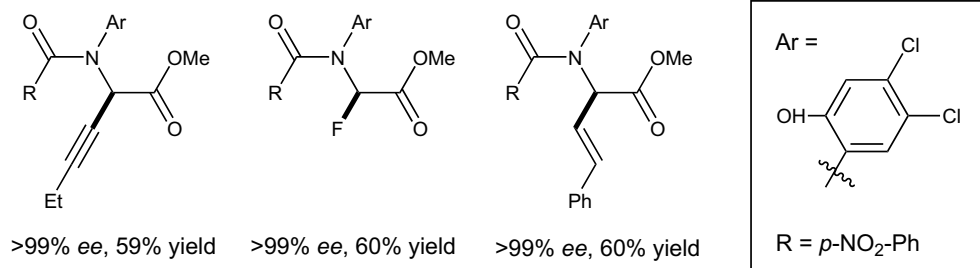

Fig. 5. Highly biologically significant amino acid derivatives

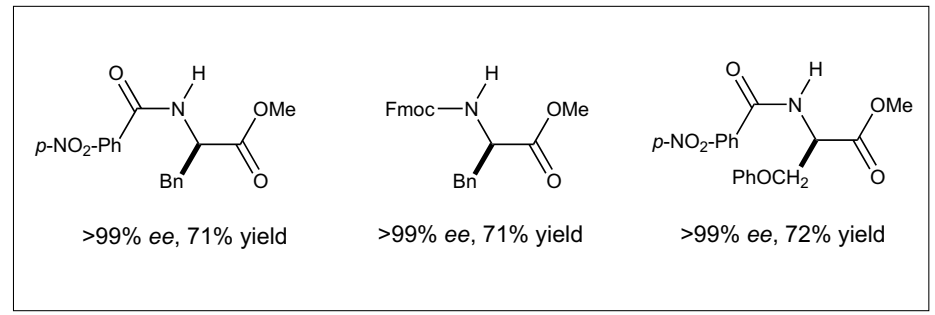

Fig. 6. $\mathrm{N}$-Protected $\alpha$-amino acid derivatives

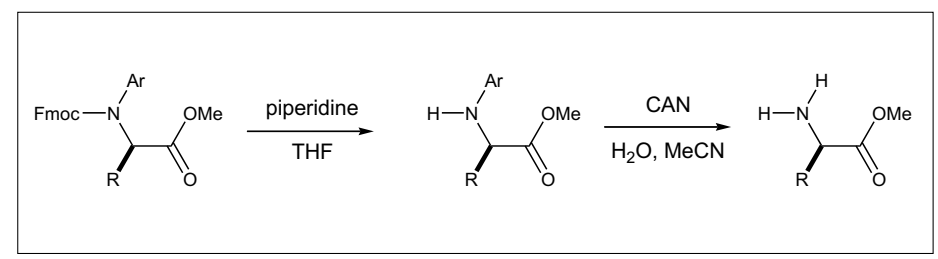

Scheme 9. Synthesis of $\mathrm{N}$-unprotected $\alpha$-amino acids variety of R-substituents, N-acyl groups, and carboalkoxy groups can be incorporated into the optically enriched products. The bicyclic products can be seen as active esters and do, indeed, react smoothly with alcohols and amines to afford $\alpha$-aminoesters and amides (Scheme 8, Fig. 4). Notably, this reaction is carried out simply by adding the desired nucleophile to the reaction pot once the cycloaddition is complete.

Among the amino acid derivative products, the most interesting are three biologically significant ${ }^{[24]}$ derivatives: $\beta, \gamma$-alkynyl amino acid, $\beta, \gamma$-alkenyl amino acid, and $\alpha$-fluoro amino acid (Fig. 5). These were produced in good yield and, once again, excellent $e e$. These three examples are of significance due not only to their high $e e$, but also to the difficulty of accessing them through other catalytic, asymmetric methodologies. ${ }^{[25]}$ Subsequent oxidation by $\mathrm{CAN}^{[26]}$ affords $\alpha$-amino acid derivatives, again without loss of ee (Fig. 6). A great variety of $\mathrm{R}$ groups (derived from the acid chloride) are possible, so that the number of non-natural amino acid derivatives accessible by this method is considerable. In the case of N-Fmoc products, removal of the protecting group with piperidine followed by CAN oxidation leads to $\mathrm{N}$-unprotected $\alpha$-amino esters in good overall yield and with full retention of enantiomeric excess (Scheme 9).

The yields for these cycloaddition reactions were good, but not as high as we would have liked. We reasoned that the sluggishness of the reaction may allow time for unwanted byproduct formation; therefore, by further activating the quinone imides, perhaps by making them more electrophilic through coordination with a Lewis acid, the reaction rate and subsequently the yield could be increased. $o$-Benzoquinone imides should be excellent candidates for Lewis acid activation. ${ }^{[27]}$ They bear a striking resemblance to the imino esters that we have successfully activated towards attack by similar catalytically derived ketene enolates. ${ }^{[28]}$ We decided to screen several metal triflates for their ability to increase the reaction rate and yield of the cycloaddtion reaction. ${ }^{[29]}$ We found that, while both zinc(II) and indium(III) increased the yield, scandium(III) had the most pronounced effect. Addition of a catalytic amount of scandium triflate to the reaction mixture provided up to a $42 \%$ increase in yield (Fig. 7). This remarkable bifunctional catalytic system (Scheme 10) improved the yield of every reaction, and, most importantly, did not degrade the enantioselectivity.

\section{4. o-Benzoquinone Diimides}

Quinoxalinones, products of the DielsAlder reaction between ketene enolates 


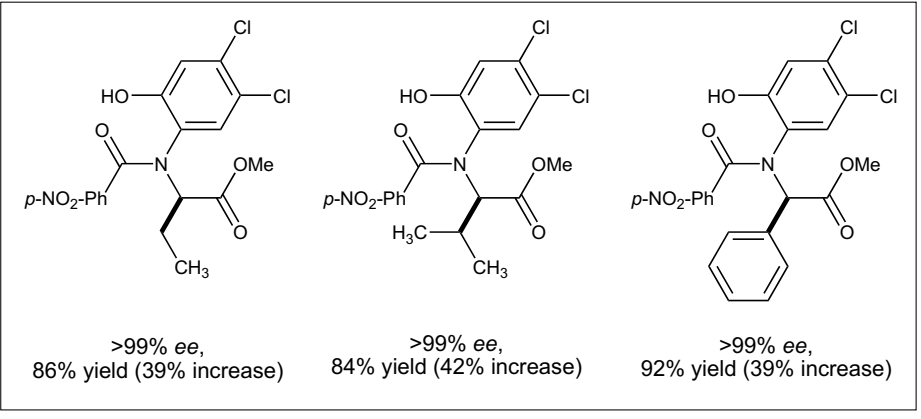

Fig. 7. Examples of improved yield for bifunctional system

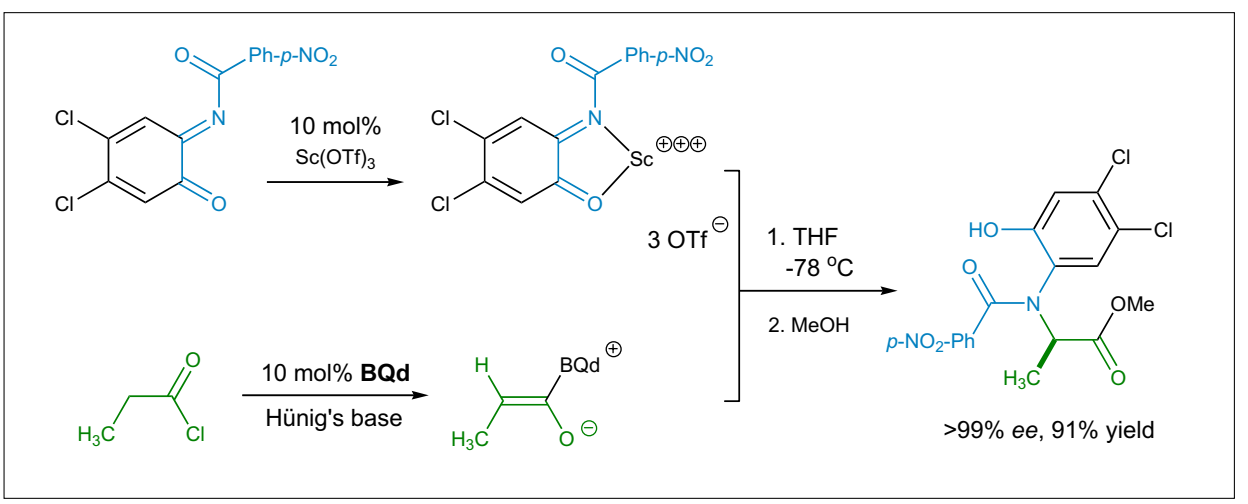

Scheme 10. Bifunctional system to form $\alpha$-amino acid derivatives

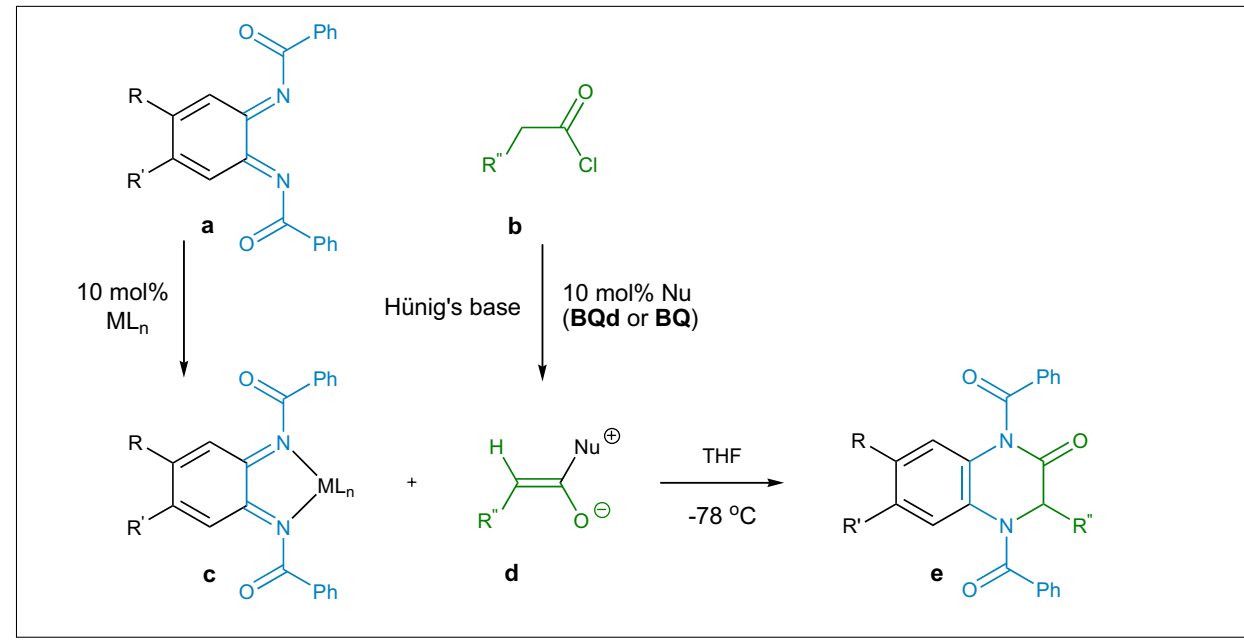

Scheme 11. Bifunctional catalytic system to produce quinoxalinones

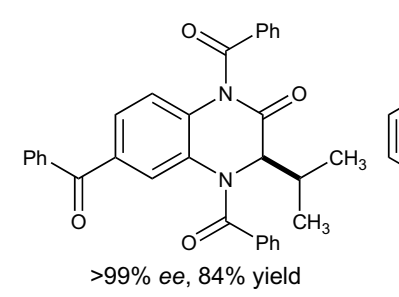<smiles>O=C(c1ccccc1)N1C(=O)C(Cc2ccccc2)N(C(=O)c2ccccc2)c2ccccc21</smiles><smiles>CC(C)CC1C(=O)N(C(=O)c2ccccc2)c2ccc(C(F)(F)F)cc2N1C(=O)c1ccccc1</smiles>

$>99 \%$ ee, $83 \%$ yield<smiles>O=C(c1ccccc1)c1ccc2c(c1)N(C(=O)c1ccccc1)C(CCCCl)C(=O)N2C(=O)c1ccccc1</smiles>

$>99 \%$ ee, $87 \%$ yield<smiles>O=C1c2ccccc2C(=O)N1CC1C(=O)N(C(=O)c2ccccc2)c2cc(Cl)c(Cl)cc2N1C(=O)c1ccccc1</smiles>

$>99 \%$ ee, $93 \%$ yield

Fig. 8. Quinoxalinone products

and $o$-benzoquinone diimides, are useful templates for drug development because of their structural relationship to benzodiazepines. ${ }^{[30]}$ These attractive targets exhibit a wide range of biological activity, including antidiabetic ${ }^{[31]}$ and antiviral effects, in particular against retroviruses such as HIV. ${ }^{[4]}$ In addition, they are partial agonists of the $\gamma$-aminobutyric acid (GABA)/benzodiazepine receptor complex, ${ }^{[32]}$ inhibitors of aldose reductase, ${ }^{[33]}$ and agonists of the AMPA and antiotensin II receptors. ${ }^{[34]}$ Related quinoxalines, which are easily made from the respective quinoxalinones by a simple reduction (see Scheme 13), also possess biological activity, for example, as inhibitors of cholesteryl ester transferase proteins. ${ }^{[35]}$

$o$-Benzoquinone diimides are easily prepared by lead(IV) oxidation of the relevant 1,2-dianilides, as outlined by Adams and Way. ${ }^{[36]}$ Initially, we screened 4,5-dichloro diimide (a, R, R' $=\mathrm{Cl}$, Scheme 11) in a reaction with butyryl chloride, Hünig's base, and BQd at $-78{ }^{\circ} \mathrm{C}$ in THF. ${ }^{[37]}$ The sluggish reaction formed several byproducts along with the desired cycloaddition product. We reasoned that activation of the diimide by coordination of a Lewis acid would render the system more electrophilic, thereby increasing the reaction rate. We screened a number of metal triflates that were chosen based on our previous success with activation of imino esters. ${ }^{[28]}$ Aluminum(III) and indium(III) provided $64 \%$ and $65 \%$ yield respectively in the standard reaction. However, scandium(III) and zinc(II) were far superior. For example, the initial rate of reaction increased by over $2000 \%$ and the product yield increased significantly $(82 \%$ for the standard reaction) when $10 \mathrm{~mol} \%$ zinc triflate was used as a cocatalyst. An IR test confirmed our notion that the Lewis acid operates through coordination with the diimide. Zinc triflate was used as a cocatalyst in subsequent reactions, providing the bifunctional catalytic system depicted in Scheme 11.

This bifunctional catalytic methodology was thoroughly screened to determine its scope. A variety of substituted quinoxalinones were produced in good to excellent yield and all products were obtained in $>99 \%$ ee (Fig. 8). In fact, we did not detect the minor enantiomer (chiral phase HPLC) in any chiral reaction. For each reaction, only one regioisomer was obtained. This highly selective methodology was rationalized by the stepwise mechanism depicted in Scheme 12.

The utility of this methodology was demonstrated through the synthesis of two drug targets. One compound, a quinoxaline that is known to inhibit cholesteryl ester transfer protein, ${ }^{[35]}$ (f, Scheme 13), was produced by reduction of the cycloaddition product. Remarkably, $\mathrm{LAH}^{[38]}$ cleaves the benzoyl groups and reduces the lactam car- 


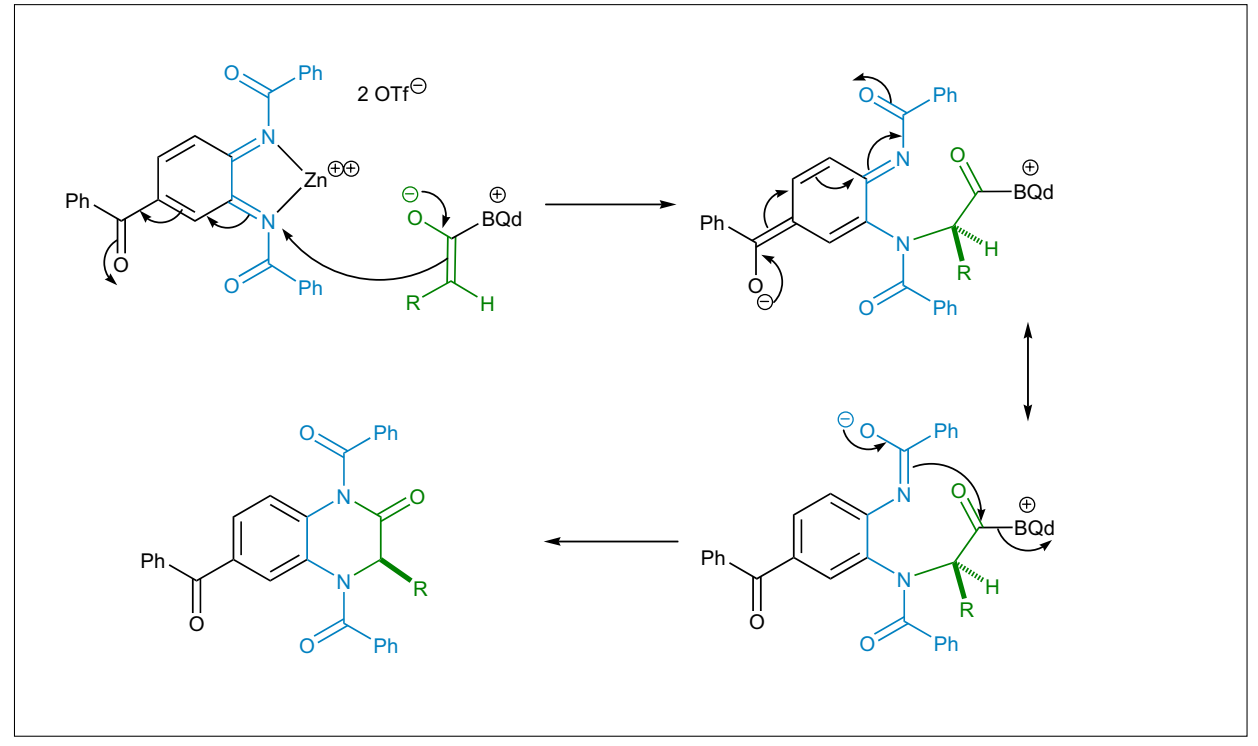

Scheme 12. Proposed mechanism of regioselective cycloaddition

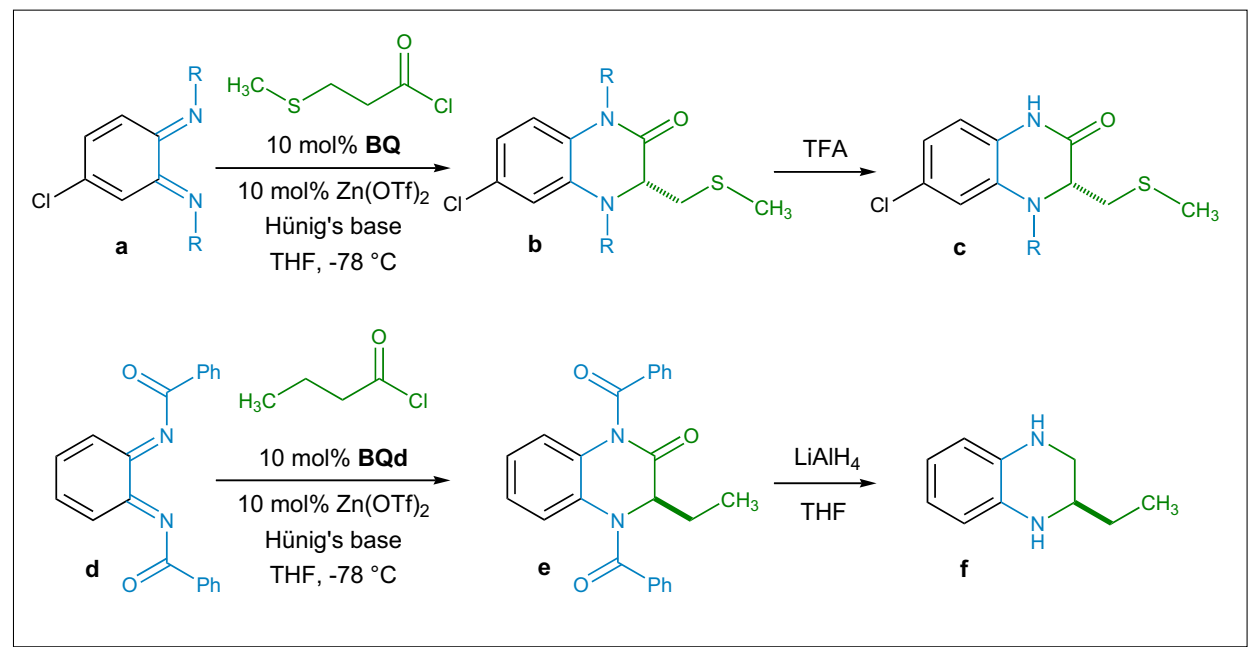

Scheme 13. Drug target syntheses, $\mathrm{R}=\mathrm{CO}_{2}-\mathrm{i}-\mathrm{Pr}$

bonyl, affording $\mathbf{f}$ in quantitative yield with full retention of $e e$. A second drug target, a quinoxalinone that exhibits strong activity against $\mathrm{HIV},{ }^{[4]}$ was produced by the remarkably regioselective cycloaddition reaction between a (Scheme 13) and 3-methylthiopropionyl chloride, mediated by cocatalysts BQ and $\mathrm{Zn}(\mathrm{OTf})_{2}$. This cycloaddition reaction gave the $(R)$-enantiomer $\mathbf{b}$ (Scheme 13) in $>99 \%$ ee and moderate yield. Selective deprotection by TFA produces the target quinoxalinone $\mathbf{c}$ in $94 \%$ yield with full retention of $e e$.

\section{Conclusion}

We have developed a highly flexible methodology for the asymmetric [4+2] cycloaddition reaction between heterodienes based on $o$-quinones and catalytically derived chiral ketene enolates. Not only are the proposed routes both novel and chemically interesting (catalytic, enantioselective reac-
[3] a) S. K. Sengupta, D. H. Trites, M. S. Madhavarao, W. R. Beltz, J. Med. Chem. 1979, 22, 797-802; b) F. Bihel, J.-L. Kraus, Org. \& Biomol. Chem. 2003, 1, 793-799; c) R. L. Jarvest, S. C. Connor, J. G. Gorniak, L. J. Jennings, H. T. Serafinowska, A. West, Bioorg. \& Med. Chem. Lett. 1997, 7, 1733-1738; d) K. F. Croom, K. L. Goa, Drugs 2003, 63, 2769-2802.

[4] M. Rösner, U.-M. Billhardt-Troughton, R. Kirsh, J.-P. Kleim, C. Meichsner, G. Riess, I. Winkler, U.S. Patent 5723461, 1998.

[5] A few precedents for enantioselective $\beta$ lactone formation: a) H. Wynberg, E. G. J. Staring, J. Am. Chem. Soc. 1982, 104, 166-168; b) M. A. Calter, J. Org. Chem. 1996, 61, 8006-8007; c) S. G. Nelson, T. J. Peelen, Z. Wan, J. Am. Chem. Soc. 1999, 121, 9742-9743; d) G. S. Cortez, R. L. Tennyson, D. Romo, J. Am. Chem. Soc. 2001, 123, 7945-7946. For $\beta$-lactam formation: e) A. E. Taggi, A. M. Hafez, H. Wack, B. Young, W. J. Drury III, T. Lectka, J. Am. Chem. Soc. 2000, 122, 7831-7832; f) B. L. Hodous, G. C. Fu, J. Am. Chem. Soc. 2002, 124, 1578-1579; g) S. France, A. Weatherwax, A. E. Taggi, T. Lectka, Acc. Chem. Res. 2004, 37, 592-600; h) S. France, M. H. Shah, A. Weatherwax, H. Wack, J. P. Roth, T. Lectka, J. Am. Chem. Soc. 2005, 127, 12061215.

[6] A. E. Taggi, A. M. Hafez, H. Wack, B. Young, D. Ferraris, T. Lectka, J. Am. Chem. Soc. 2002, 124, 6626-6635.

[7] a) 'The Chemistry of the Quinonoid Compounds', Ed. S. Patai, John Wiley \& Sons, New York, 1974, 4 vols. For a recent review see: b) B. I. Kharisov, M. A. MendezRojas, A. D. Garnovskii, E. P. Ivakhnenko, U. Ortiz-Mendez, J. Coord. Chem. 2002, 55, 745-770.

[8] Some examples include: a) D. D. Weller, E. P. Stirchak, J. Org. Chem. 1983, 48, 4873-4879; b) I. W. Sinclair, G. R. Proctor, J. Chem. Soc., Perkin Trans. $1 \mathbf{1 9 7 5 ,}$ 23, 2485-2488; c) R. Willstaetter, A. Pfannenstiel, Ber. Dtsch. Chem. Ges. 1904, 37 , 4744-4746; d) F. Minisci, A. Citterio, E. Vismara, F. Fontana, S. De Bernardinis, M. Correale, J. Org. Chem. 1989, 54, 728-731.

[9] D. Magdziak, A. A. Rodriguez, R. W. Van De Water, T. R. R. Pettus, Org. Lett. 2002, 4, 285-288.

$\overline{[1]}$ a) J. D. White, Y. Choi, Org. Lett. 2000, 2, 2373-2376; b) J. D. White, Y. Choi, Helv. Chim. Acta 2002, 85, 4306-4327; c) D. A. Evans, J. Wu, J. Am. Chem. Soc. 2003, 125, 10162-10163; d) D. H. Ryu, G. Zhou, E. J. Corey, J. Am. Chem. Soc. 2004, 126, 4800-4802; e) Q. -Y. Hu, G. Zhou, E. J. Corey, J. Am. Chem. Soc. 2004, 126, 13708-13713.

[2] O. B. Wallace, D. W. Smith, M. S. Deshpande, C. Polson, K. M. Felsenstein, Bioorg. \& Med. Chem. Lett. 2003, 13, 1203-1206.
[10] a) W. Ried, E. Torok, Liebigs Ann. Chem. 1965, 687, 187-190; b) K. T. Finley, 'Quinones as Synthones', in 'The Chemistry of Quinonoid Compounds', Ed. S. Patai, Wiley \& Sons, New York, 1988, Vol. 2(Pt. 1), pp. 537-717.

[11] a) D. Bryce-Smith, A. Gilbert, Chem. Commun. 1968, 21, 1319-1320; b) C. Liao, H. Lin, J. Lin, J. Chin. Chem. Soc. 1980, 27, 87-95.

[12] a) V. Nair, S. Kumar, J. Chem. Soc., Perkin Trans. 1 1996, 5, 443-447; b) J. Kaizer, 
G. Speier, E. Osz, M. Giorgi, M. Reglier, Tetrahedron Lett. 2004, 45, 8011-8013.

[13] T. Bekele, M. H. Shah, J. Wolfer, C. J. Abraham, A. Weatherwax, T. Lectka, J. Am. Chem. Soc. 2006, 128, 1810-1811.

[14] A. E. Taggi, A. M. Hafez, T. Dudding, T. Lectka, Tetrahedron 2002, 58, 83518356.

[15] a) M. Largeron, B. Lockhart, B. Pfeiffer, M.-B. Fleury, J. Med. Chem. 1999, 42, 5043-5052; b) M. Largeron, M.-B. Fleury, Tetrahedron Lett. 1998, 39, 8999-9002.

[16] K. C. Nicolaou, Y. Zhong, P. S. Baran, K. Sugita, Angew. Chem., Int. Ed. 2001, 40, 2145-2149.

[17] H. W. Heine, D. K. Williams, J. L. Rutherford, J. Ramphal, E. A. Williams, Heterocycles 1993, 35, 1126-1140.

[18] J. Wolfer, T. Bekele, C. J. Abraham, C. Dogo-Isonagie, T. Lectka, Angew. Chem., Int. Ed. 2006, 45, 7398-7400.

[19] P. Verma, S. Singh, D. K. Dikshit, R. Suprabhat, Synthesis 1987, 68-70.

[20] a) S. Bhaduri, G. K. Lahiri, P. Munshi, $J$. Organomet. Chem. 2000, 606, 151-155; b) S. Gladiali, A. Dore, D. Fabbri, S. Medici, G. Pirri, S. Pulacchini, Eur. J. Org. Chem. 2000, 16, 2861-2866; c) M. T. Reetz, G. Mehler, Tetrahedron Lett. 2003 , 44, 4593-4596.

[21] a) S. Kobayashi, R. Matsubara, Y. Nakamura, H. Kitagawa, M. Sugiura, J. Am. Chem. Soc. 2003, 125, 2507-2515; b) R. Matsubara, Y. Nakamura, S. Kobayashi, Angew. Chem., Int. Ed. 2004, 43, 16791681.

[22] M. J. O'Donnell, Acc. Chem. Res. 2004, 37, 506-517.

[23] a) H. Groeger, Chem. Rev. 2003, 103, 2795-2827; b) J. Huang, E. J. Corey, Org. Lett. 2004, 6, 5027-5029; c) C. Becker, C. Hoben, D. Schollmeyer, G. Scherr, H. Kunz, Eur. J. Org. Chem. 2005, 8, 14971499.

[24] P. Meffre, F. Le Goffic, Amino Acids 1996, 11,313 .
[25] a) D. P. Huber, K. Stanek, A. Togni, Tetrahedron: Asymm. 2006, 17, 658; b) B. Mohar, J. Baudoux, J.-C. Plaquevent, D. Cahard, Angew. Chem., Int. Ed. 2001, 40 , 4214.

[26] S. Kobayashi, J. Kobayashi, H. Ishiani, M. Ueno, Chem. Eur. J. 2002, 8, 4185-4190.

[27] See for example: C. B. Castellani, G. Gatti, R. Millini, Inorg. Chem. 1984, 23, 4004-4008.

[28] a) S. France, H. Wack, A. M. Hafez, A. E. Taggi, D. R. Witsil, T. Lectka, Org. Lett. 2002, 4, 1603-1605; b) D. Ferraris, B. Young, C. Cox, T. Dudding, W. J. Drury, L. Ryzhkov, A.E. Taggi, T. Lectka, J. Am. Chem. Soc. 2002, 124, 67-77.

[29] D. H. Paull, E. Alden-Danforth, J. Wolfer, C. Dogo-Isonagie, C. J. Abraham, T. Lectka, J. Org. Chem. 2007, in press.

[30] D. A. Horton, G. T. Bourne, M. L. Smythe, Chem. Rev. 2003, 103, 893-930, and references therein.

[31] D. Gupta, N. N. Ghosh, R. Chandra, Bioorg. Med. Chem. Lett. 2005, 15, 10191022.

[32] L. Lee, W. V. Murray, R. A. Rivero, J. Org. Chem. 1997, 62, 3874-3879, and references therein.

[33] a) R. Sarges, J. W. Lyga, J. Heterocycl. Chem. 1988, 25, 1475-1479; b) B. A. Bunin, J. A. Ellman, J. Am. Chem. Soc. 1992, 114, 10997-10998.

[34] G. A. Morales, J. W. Corbett, W. F. DeGrado, J. Org. Chem. 1998, 63, 1172-1177.

[35] Z. Jones, R. Groneberg, M. Drew, C. T. Eary, U.S. Patent 20050282812, 2005.

[36] R. Adams, J. W. Way, J. Am. Chem. Soc. 1954, 76, 2763-2769.

[37] C. J. Abraham, D. H. Paull, M. T. Scerba, J. W. Grebinski, T. Lectka, J. Am. Chem. Soc. 2006, 128, 13370-13371.

[38] M. Ikeda, K. Ohno, T. Uno, Y. Tamura, Tetrahedron Lett. 1980, 21, 3403-3406. 